\title{
Editorial
}

\section{Eberhard F. Mammen Award Announcements: Part I-Most Popular Articles}

\author{
Emmanuel J. Favaloro, PhD, FFSc (RCPA) ${ }^{1}$ \\ ${ }^{1}$ Department of Haematology, Institute of Clinical Pathology and \\ Medical Research (ICPMR), Westmead Hospital, Westmead, \\ Australia
}

Semin Thromb Hemost 2017;43:357-363.

Welcome to the latest of our Eberhard F. Mammen award announcements. As noted previously, ${ }^{1-3}$ Thieme, the publisher of Seminars in Thrombosis \& Hemostasis, has created the "Eberhard F. Mammen Excellence in Thrombosis and Hemostasis Awards" in honor of Eberhard F. Mammen (-Fig. 1), and in recognition of his contribution to this field and to the journal that he both founded and steered for over three decades. These awards began in 2009, under two categories, "Most Popular Article Award" and "Young Investigator Award." Current details and conditions of the award can be summarized as follows:

Most Popular Article Awards: Awarded to the authors of the most popular articles published in Seminars in Thrombosis \& Hemostasis. The awards are determined by the Editor in Chief on the basis of user statistics from Thieme e-Journals from the preceding 2 years. Prefaces, Errata, Letters to the Editor, Editorials, and previous award winning articles are excluded from further consideration of these awards, which currently comprise two categories-one for "Open Access" articles, and another for a "General Category." There are two major cash prizes of US $\$ 1,000$ for each category. In addition, winners of the "General Category" awards are granted "open access" status for these articles thereafter.

$>$ Young Investigator Awards: Best presentation or meeting abstract by a young investigator-as presented or delivered to an international or large regional meeting on a topic related to the fields of thrombosis and hemostasis, and whose subject matter is determined to be in the spirit of Dr. Mammen. Up to six cash prizes of US $\$ 1,000$ in any year. There are some additional considerations and conditions for the award, and awardees are expected to prepare a review or other article related to the topic of their presentation for publication in Seminars in Thrombosis E' Hemostasis.

Address for correspondence E.J. Favaloro, PhD, FFSc (RCPA), Department of Haematology, Institute of Clinical Pathology and Marcel Levi, MD, PhD. Medical Research (ICPMR),

Westmead Hospital, Westmead,

NSW 2145, Australia

(e-mail: emmanuel.

favaloro@health.nsw.gov.au).

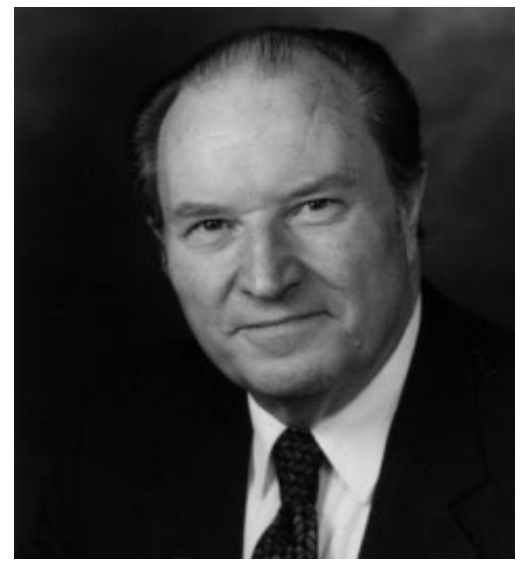

Fig. 1 Eberhard F Mammen (1930-2008).

Further details of the awards and the award winners are posted online (http://www.thieme.com/sth), and previous award winner announcements are also available in print. ${ }^{4-14}$

It is therefore with great pleasure that we would like to announce the latest winners of the 2017 Eberhard F. Mammen Awards for the most popular articles from Seminars in Thrombosis \& Hemostasis for the period of 2015-2016 inclusive. We will be announcing the Young Investigator Awards related to meetings held in the recent past at a forthcoming opportunity.

\section{7 “Most Popular” Article Awards}

As mentioned, the Most Popular Awards are given to the authors of the most popular articles published in Seminars in Thrombosis $\mathcal{E}$ Hemostasis as determined on the basis of user statistics from the publisher of this journal and covering the preceding 2-year period. Thus, the 2017 "Most Popular"

Copyright (c 2017 by Thieme Medical Publishers, Inc., 333 Seventh Avenue, New York, NY 10001, USA Tel: +1(212) 584-4662.
DOI https://doi.org/ 10.1055/s-0037-1601457. ISSN 0094-6176.
Issue Theme Point-of-Care Testing in Acute Hemorrhagic and Thrombotic States; Guest Editor: 
awards are granted to the most popular articles from 2015 to 2016 inclusive. Previous Eberhard F. Mammen Award winning articles are listed in -Table 1. These articles are currently available under an "Open Access" status, and no longer qualify for future awards, although many will continue to appear in the most popular download statistics provided by the publisher.

There is also an increasingly recognized trend to publish articles in an open-access mode, and these have an "inequi- table advantage" over other "non-open access" articles in terms of downloads due to their open accessibility. Accordingly, the publisher of Seminars in Thrombosis \& Hemostasis has established a separate category of the Most Popular Award for "open-access" articles, to supplement the alternate "General Category," and thus the most popular articles are now listed in separate tables. - Table 2 lists the top 15 downloaded "open access" articles from Seminars in Thrombosis \& Hemostasis (2015 and 2016 inclusive) eligible for the

Table 1 Previous Most Popular award winning articles

\begin{tabular}{|c|c|}
\hline Year & Awarded For \\
\hline 2009 & Jurk K, Kehrel BE. Platelets: physiology and biochemistry. Semin Thromb Hemost 2005;31(4):381-392 \\
\hline 2009 & Girolami B, Girolami A. Heparin-induced thrombocytopenia: a review. Semin Thromb Hemost 2006;32(8):803-809 \\
\hline 2010 & $\begin{array}{l}\text { Harenberg J, Wehling M. Current and future prospects for anticoagulant therapy: inhibitors of factor Xa and factor } \\
\text { Ila. Semin Thromb Hemost 2008;34(1):39-57 }\end{array}$ \\
\hline 2010 & $\begin{array}{l}\text { Prechel M, Walenga JM. The laboratory diagnosis and clinical management of patients with heparin-induced } \\
\text { thrombocytopenia: an update. Semin Thromb Hemost 2008;34(1):86-96 }\end{array}$ \\
\hline 2010 & $\begin{array}{l}\text { Fareed J, Hoppensteadt DA, Fareed D, Demir M, Wahi R, Clarke M, Adiguzel C, Bick R. Survival of heparins, oral } \\
\text { anticoagulants, and aspirin after the year 2010. Semin Thromb Hemost 2008;34(1):58-73 }\end{array}$ \\
\hline 2011 & $\begin{array}{l}\text { Sobieraj-Teague M, O’Donnell M, Eikelboom J. New anticoagulants for atrial fibrillation. Semin Thromb Hemost } \\
\text { 2009;35(5):515-524 }\end{array}$ \\
\hline 2011 & Mariani G, Bernardi F. Factor VII deficiency. Semin Thromb Hemost 2009;35(4):400-406 \\
\hline 2012 & $\begin{array}{l}\text { Lippi G, Franchini M, Favaloro EJ, Targher G. Moderate red wine consumption and cardiovascular disease risk: } \\
\text { beyond the "French paradox." Semin Thromb Hemost 2010;36(1):59-70 }\end{array}$ \\
\hline 2012 & Rak J. Microparticles in cancer. Semin Thromb Hemost 2010;36(8):888-906 \\
\hline 2013 & $\begin{array}{l}\text { Fava C, Montagnana M, Favaloro EJ, Guidi GC, Lippi G. Obstructive sleep apnea syndrome and cardiovascular } \\
\text { diseases. Semin Thromb Hemost 2011;37(3):280-297 }\end{array}$ \\
\hline 2013 & $\begin{array}{l}\text { Tufano A, Guida A, Di Minno MN, Prisco D, Cerbone AM, Minno GD. Prevention of venous thromboembolism in } \\
\text { medical patients with thrombocytopenia or with platelet dysfunction: a review of the literature. Semin Thromb } \\
\text { Hemost } 2011 ; 37(3): 267-274\end{array}$ \\
\hline 2014 & $\begin{array}{l}\text { Salmela B, Joutsi-Korhonen L, Armstrong E, Lassila R. Active online assessment of patients using new oral } \\
\text { anticoagulants: bleeding risk, compliance, and coagulation analysis. Semin Thromb Hemost 2012;38(1):23-30 }\end{array}$ \\
\hline 2014 & $\begin{array}{l}\text { Chapman K, Seldon M, Richards R. Thrombotic microangiopathies, thrombotic thrombocytopenic purpura, and } \\
\text { ADAMTS-13. Semin Thromb Hemost 2012;38(1):47-54 }\end{array}$ \\
\hline 2014 & $\begin{array}{l}\text { Kenet G, Aronis S, Berkun Y, Bonduel M, Chan A, Goldenberg NA, Holzhauer S, lorio A, Journeycake J, Junker R, Male } \\
\text { C, Manco-Johnson M, Massicotte P, Mesters R, Monagle P, van Ommen H, Rafini L, Simioni P, Young G, Nowak- } \\
\text { Göttl U. Impact of persistent antiphospholipid antibodies on risk of incident symptomatic thromboembolism in } \\
\text { children: a systematic review and meta-analysis. Semin Thromb Hemost 2011;37(7):802-809 }\end{array}$ \\
\hline 2015 & Tapson VF. Thrombolytic therapy for acute pulmonary embolism. Semin Thromb Hemost 2013;39(4):452-458 \\
\hline 2015 & $\begin{array}{l}\text { George JN, Charania RS. Evaluation of patients with microangiopathic hemolytic anemia and thrombocytopenia. } \\
\text { Semin Thromb Hemost 2013;39(2):153-160 }\end{array}$ \\
\hline $2015^{a}$ & Hylek EM. Anticoagulation therapy for atrial fibrillation. Semin Thromb Hemost 2013;39(2):147-152 \\
\hline $2015^{\mathrm{a}}$ & Rojas-Hernandez CM, Garcia DA. The novel oral anticoagulants. Semin Thromb Hemost 2013;39(2):117-126 \\
\hline 2016 & $\begin{array}{l}\text { de Moerloose P, Casini A, Neerman-Arbez M. Congenital fibrinogen disorders: an update. Semin Thromb Hemost } \\
\text { 2013;39(6):585-595 }\end{array}$ \\
\hline 2016 & $\begin{array}{l}\text { Sethi S, Fervenza FC. Pathology of renal diseases associated with dysfunction of the alternative pathway of } \\
\text { complement: C3 glomerulopathy and atypical hemolytic uremic syndrome (aHUS). Semin Thromb Hemost } \\
\text { 2014;40(4):416-421 }\end{array}$ \\
\hline $2016^{\mathrm{a}}$ & $\begin{array}{l}\text { Bates SM. D-dimer assays in diagnosis and management of thrombotic and bleeding disorders. Semin Thromb } \\
\text { Hemost 2012;38(7):673-682 }\end{array}$ \\
\hline $2016^{a}$ & $\begin{array}{l}\text { Lippi G, Favaloro EJ, Meschi T, Mattiuzzi C, Borghi L, Cervellin G. E-cigarettes and cardiovascular risk: beyond science } \\
\text { and mysticism. Semin Thromb Hemost 2014;40(1):60-65 }\end{array}$ \\
\hline
\end{tabular}

${ }^{\mathrm{a}}$ New open access category. 
"Open Access" award. ${ }^{15-28}$ - Table 3 lists the top 15 downloaded non-open access articles from Seminars in Thrombosis $\mathcal{E}$ Hemostasis (2015 and 2016 inclusive) eligible for the "General category" award. ${ }^{29-43}$

Accordingly, the 2017 Eberhard F. Mammen Award winners for most popular article (2015/2016 inclusive) are as follows:

\section{Open Access Category}

1. Moore GW. Recent guidelines and recommendations for laboratory detection of lupus anticoagulants. Semin Thromb Hemost 2014;40(2):163-171.

2. Warkentin TE. Heparin-induced thrombocytopenia in critically ill patients. Semin Thromb Hemost 2015;41(1): 49-60.

(Although I was the lead author on one of the most popular articles listed in $\mathbf{- T a b l e ~} \mathbf{2}$, I will preclude myself from receipt of the award, which will be granted to the next article in sequence).

\section{General Category}

1. Boonyawat K, Crowther MA. Venous thromboembolism prophylaxis in critically ill patients. Semin Thromb Hemost 2015;41(1):68-74.

2. Levi M, Poll TV. Coagulation in patients with severe sepsis. Semin Thromb Hemost 2015;41(1):9-15.

It is interesting to me that several issues seem to have caught the attention of the readership. In particular, the issue "Thrombosis and Hemostasis Issues in Critically Ill Patients," 44 guest edited by Marcel Levi, has several articles in the top listings, as does the issue "Anticoagulant Therapy: Present and Future," 45 guest edited by Job Harenberg. Indeed, the issue "Thrombosis and Hemostasis Issues in Critically Ill Patients" managed to grab three of the four available awards, with a total of five articles listed in - Tables 2 and 3. Similarly, although the issue "Anticoagulant Therapy: Present and Future" missed out on the "Most Popular" awards, it lists four articles in -Tables 2 and 3.

Table 2 Most popular papers-“Open Access” category ${ }^{a}$

\begin{tabular}{|c|c|}
\hline Rank & Publication \\
\hline 1 & $\begin{array}{l}\text { Moore GW. Recent guidelines and recommendations for laboratory detection of lupus anticoagulants. Semin } \\
\text { Thromb Hemost 2014;40(2):163-171 }\end{array}$ \\
\hline 2 & $\begin{array}{l}\text { Favaloro EJ, Lippi G. Laboratory testing in the era of direct or non-vitamin K antagonist oral anticoagulants: a } \\
\text { practical guide to measuring their activity and avoiding diagnostic errors. Semin Thromb Hemost 2015;41(2): } \\
208-227\end{array}$ \\
\hline 3 & Warkentin TE. Heparin-induced thrombocytopenia in critically ill patients. Semin Thromb Hemost 2015;41(1):49-60 \\
\hline 4 & $\begin{array}{l}\text { Cuker A. Clinical and laboratory diagnosis of heparin-induced thrombocytopenia: an integrated approach. Semin } \\
\text { Thromb Hemost 2014;40(1):106-114 }\end{array}$ \\
\hline 5 & $\begin{array}{l}\text { Demers M, Wagner DD. NETosis: a new factor in tumor progression and cancer-associated thrombosis. Semin } \\
\text { Thromb Hemost 2014;40(3):277-283 }\end{array}$ \\
\hline 6 & $\begin{array}{l}\text { Raskob GE, Angchaisuksiri P, Blanco AN, Büller H, Gallus A, Hunt BJ, Hylek EM, Kakkar TL, Konstantinides SV, } \\
\text { McCumber M, Ozaki Y, Wendelboe A, Weitz Jl; ISTH Steering Committee for World Thrombosis Day. Thrombosis: a } \\
\text { major contributor to global disease burden. Semin Thromb Hemost 2014;40(7):724-735 }\end{array}$ \\
\hline 7 & $\begin{array}{l}\text { Cuker A, Prak ET, Cines DB. Can immune thrombocytopenia be cured with medical therapy? Semin Thromb Hemost } \\
\text { 2015;41(4):395-404 }\end{array}$ \\
\hline 8 & Althaus K, Greinacher A. MYH9-related platelet disorders. Semin Thromb Hemost 2009;35(2):189-203 \\
\hline 9 & Favaloro EJ. Clinical utility of the PFA-100. Semin Thromb Hemost 2008;34(8):709-733 \\
\hline 10 & $\begin{array}{l}\text { Zolfaghari S, Harenberg J, Froelich L, Wehling M, Weiss C. Development of a tool to identify patients' preference for } \\
\text { vitamin k antagonist or direct oral anticoagulant therapy. Semin Thromb Hemost 2014;40(1):121-128 }\end{array}$ \\
\hline 11 & $\begin{array}{l}\text { Harenberg J, Du S, Krämer S, Weiss C, Krämer R, Wehling M. Patients' serum and urine as easily accessible samples for the } \\
\text { measurement of non-vitamin K antagonist oral anticoagulants. Semin Thromb Hemost 2015;41(2):228-236 }\end{array}$ \\
\hline 12 & Nurden AT. Platelet membrane glycoproteins: a historical review. Semin Thromb Hemost 2014;40(5):577-584 \\
\hline 13 & $\begin{array}{l}\text { Wada H, Usui M, Sakuragawa N. Hemostatic abnormalities and liver diseases. Semin Thromb Hemost 2008;34 } \\
\text { (8):772-778 }\end{array}$ \\
\hline 14 & $\begin{array}{l}\text { Zolfaghari S, Harenberg J, Froelich L, Wehling M, Weiss C. Development of a tool to identify patients' preference for } \\
\text { vitamin k antagonist or direct oral anticoagulant therapy. Semin Thromb Hemost 2014;40(1):121-128 }\end{array}$ \\
\hline 15 & Italiano JE Jr. Unraveling mechanisms that control platelet production. Semin Thromb Hemost 2013;39(1):15-24 \\
\hline
\end{tabular}

a2015-2016 inclusive; excludes nonqualifying material (e.g., Prefaces, Errata, Letters to the Editor, Editorials, and previous award winning articles). 
Table 3 Most popular articles-“General” category ${ }^{a}$

\begin{tabular}{|c|c|}
\hline Rank & Publication \\
\hline 1 & $\begin{array}{l}\text { Boonyawat K, Crowther MA. Venous thromboembolism prophylaxis in critically ill patients. Semin Thromb Hemost } \\
\text { 2015;41(1):68-74 }\end{array}$ \\
\hline 2 & Levi M, Poll TV. Coagulation in patients with severe sepsis. Semin Thromb Hemost 2015;41(1):9-15 \\
\hline 3 & $\begin{array}{l}\text { Senoo K, Lip GY. Comparative efficacy and safety of the non-vitamin K antagonist oral anticoagulants for patients } \\
\text { with nonvalvular atrial fibrillation. Semin Thromb Hemost } 2015 ; 41(2): 146-153\end{array}$ \\
\hline 4 & $\begin{array}{l}\text { Mallett SV. Clinical utility of viscoelastic tests of coagulation (TEG/ROTEM) in patients with liver disease and during } \\
\text { liver transplantation. Semin Thromb Hemost 2015;41(5):527-537 }\end{array}$ \\
\hline 5 & $\begin{array}{l}\text { McMahon BJ, Kwaan HC. The new or non-vitamin Kantagonist oral anticoagulants: what have we learned since their } \\
\text { debut. Semin Thromb Hemost 2015;41(2):188-194 }\end{array}$ \\
\hline 6 & Ranucci M. Hemostatic and thrombotic issues in cardiac surgery. Semin Thromb Hemost 2015;41(1):84-90 \\
\hline 7 & Baskurt OK, Meiselman HJ. Blood rheology and hemodynamics. Semin Thromb Hemost 2003;29(5):435-450 \\
\hline 8 & Boccardo P, Remuzzi G, Galbusera M. Platelet dysfunction in renal failure. Semin Thromb Hemost 2004;30(5):579-589 \\
\hline 9 & $\begin{array}{l}\text { Riedl M, Fakhouri F, Le Quintrec M, Noone DG, Jungraithmayr TC, Fremeaux-Bacchi V, Licht C. Spectrum of } \\
\text { complement-mediated thrombotic microangiopathies: pathogenetic insights identifying novel treatment } \\
\text { approaches. Semin Thromb Hemost 2014;40(4):444-464 }\end{array}$ \\
\hline 10 & Gando S. Hemostasis and thrombosis in trauma patients. Semin Thromb Hemost 2015;41(1):26-34 \\
\hline 11 & $\begin{array}{l}\text { Intagliata NM, Northup PG. Anticoagulant therapy in patients with cirrhosis. Semin Thromb Hemost 2015;41 } \\
\text { (5):514-519 }\end{array}$ \\
\hline 12 & $\begin{array}{l}\text { Semeraro N, Ammollo CT, Semeraro F, Colucci M. Coagulopathy of acute sepsis. Semin Thromb Hemost 2015;41 } \\
\text { (6):650-658 }\end{array}$ \\
\hline 13 & Duga S, Salomon O. Congenital factor XI deficiency: an update. Semin Thromb Hemost 2013;39(6):621-631 \\
\hline 14 & $\begin{array}{l}\text { McEwen BJ. The influence of herbal medicine on platelet function and coagulation: a narrative review. Semin } \\
\text { Thromb Hemost 2015;41(3):300-314 }\end{array}$ \\
\hline 15 & $\begin{array}{l}\text { Franchini M, Bonfanti C, Mannucci PM. Management of bleeding associated with new oral anticoagulants. Semin } \\
\text { Thromb Hemost 2015;41(7):788-801 }\end{array}$ \\
\hline
\end{tabular}

a2015-2016 inclusive; excludes nonqualifying material (e.g., Prefaces, Errata, Letters to the Editor, Editorials, and previous award winning articles).

All authors of the award-winning articles were thrilled to hear that their articles had won an Eberhard F. Mammen Most Popular award, and provided the following additional responses:

From Dr. Gary Moore (-Fig. 2), "I am truly honored to receive this award because it reflects a degree of interest from within our scientific community, which is both amazing and humbling. Writing the review was a labor of love, as lupus anticoagulant detection continues to fascinate, intrigue, and at times frustrate me. The relatively close publication of guidelines from three expert panels on how to detect these sometimes elusive antibodies was a fantastic opportunity to compare and contrast their recommendations, discuss some of the differences, and try to clarify some of the ambiguities. As a coauthor of two of the guidelines, I was in a good position to understand how different groups worked together to come to their sometimes similar/sometimes diverse conclusions, and hope I nonetheless managed to be informative and objective in my synopsis. One always hopes that a publication will touch many professional lives, and thus to win this award confirms this to be so."

From Dr. Theodore (Ted) Warkentin (-Fig. 3), "I was delighted to receive the wonderful-and unexpected-news that this heparin-induced thrombocytopenia (HIT) paper was identified as one of the 'most popular articles'. Indeed, I like to share this paper with our McMaster hematology residents, as its concluding 1-page Appendix summarizes a helpful diagnostic and treatment approach to HIT; and the paper also addresses some vexing diagnostic issues, such as

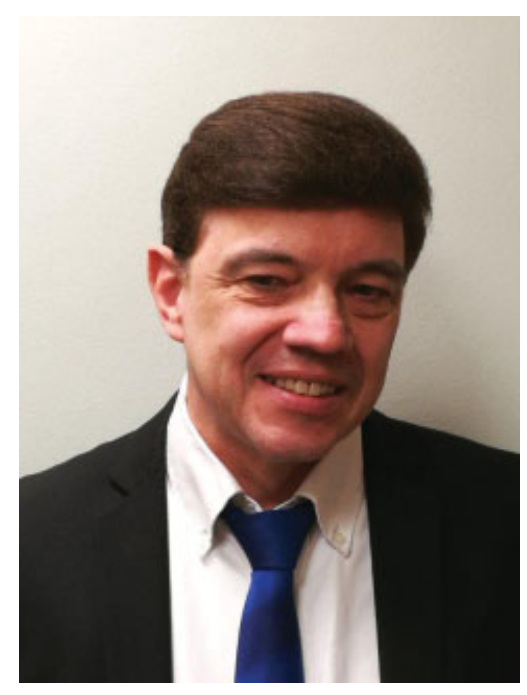

Fig. 2 Dr. Gary Moore. 


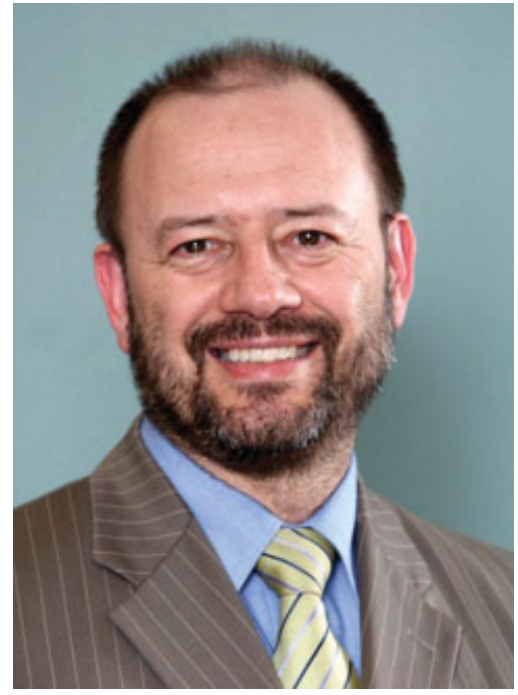

Fig. 3 Dr. Theodore (Ted) Warkentin.

how to distinguish DIC-associated ischemic limb injury from that caused by HIT. I also would like to thank Professor Marcel Levi (University of Amsterdam), the Guest Editor of the issue ('Thrombosis and Hemostasis Issues in Critically Ill Patients') in which the HIT paper appears, for inviting the paper, and for overseeing the entire volume."

From Drs. Mark Crowther ( - Fig. 4) and Kochawan Boonyawat ( - Fig. 5), "We would like to thank the publishers for the honor of receiving the 'Eberhard F. Mammen' Award. Receiving such an award is one of the rare ways that we, as authors, realize the impact that our work is having. Review articles are undervalued in the scientific community because they are perceived to be less rigorous than 'original science.' Such awards, however, remind us that for most clinicians it is summaries and overviews that guide their practice. Seminars in Thrombosis \& Hemostasis has always been regarded as a

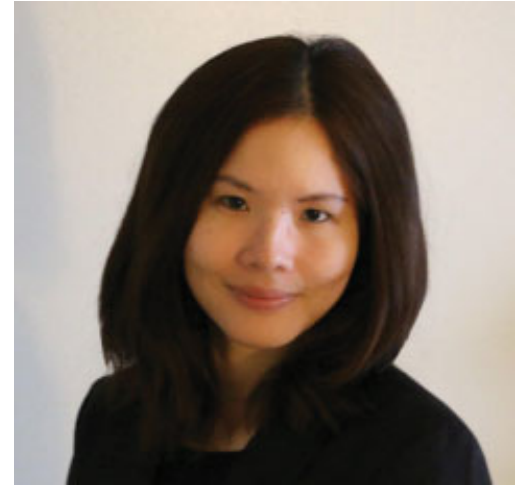

Fig. 5 Dr. Kochawan Boonyawat.

leading journal for high quality reviews across the spectrum of thrombosis and hemostasis; thus, to receive this award is a rare honor given the outstanding authorship list that this journal is able to command. It is also a great pleasure to find a journal that has put in place such an award for authors fortunate to work in areas of high clinical and research interest-the journal is to be congratulated on making this effort which is almost, in my opinion, unique. We look forward to working with Seminars in Thrombosis \& Hemostasis in the future and to provide further contributions to the literature in this area."

From Dr. Marcel Levi (-Fig. 6), also on behalf of his coauthor Dr. Tom van der Poll ( - Fig. 7), "I am most honored that this article has attracted so much attention. It is, in particular, wonderful that an article building on the work of Eberhard F. Mammen, published in the journal for which he was the leading editor for many years, now awards a prize in his name. I am really very proud. It is always very good to learn that a review article is well received and read by many

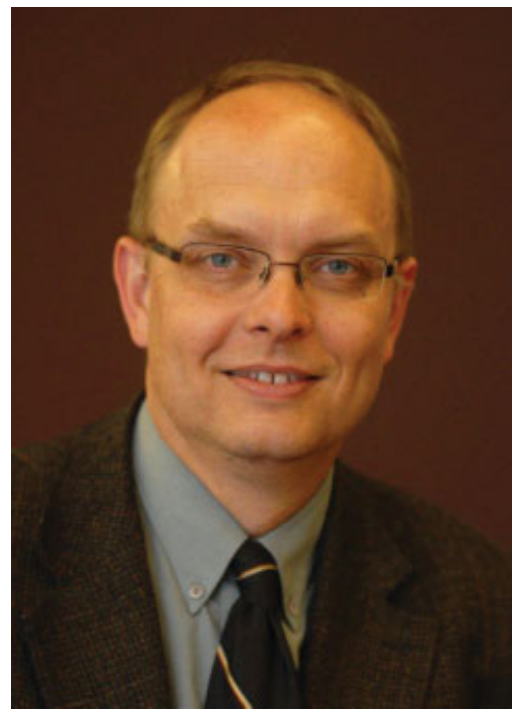

Fig. 4 Dr. Mark Crowther.

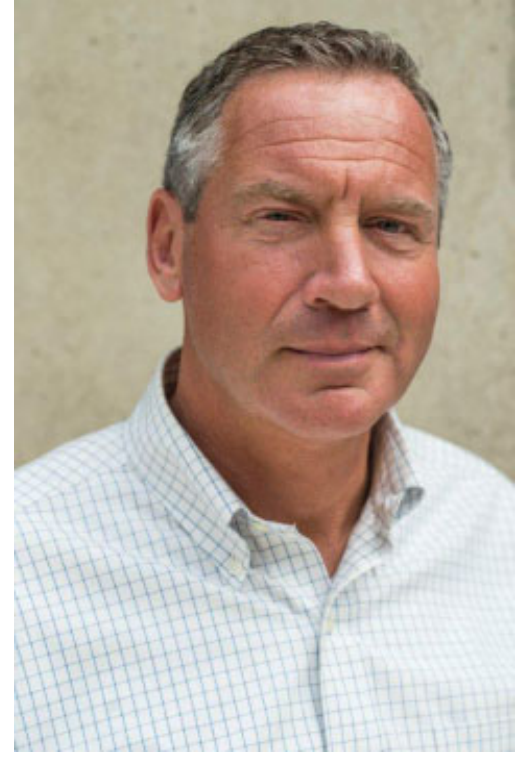

Fig. 6 Dr. Marcel Levi. 


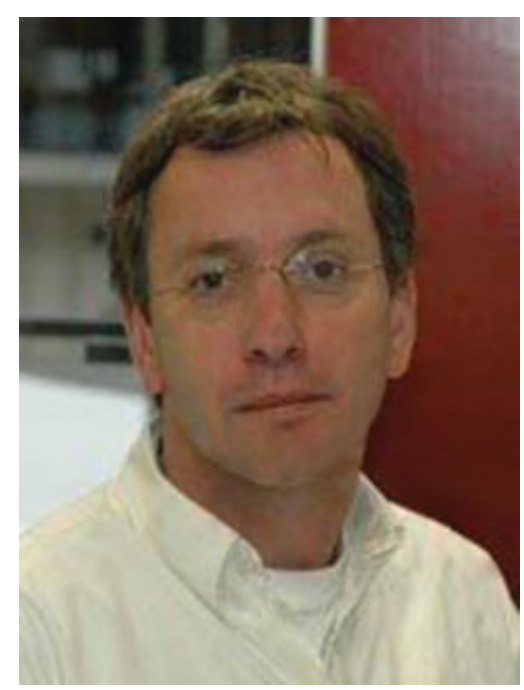

Fig. 7 Dr. Tom van der Poll.

colleagues and I can only hope it has been helpful for practicing physicians and researchers in this field."

I would like as always to thank not only all of the authors listed in the tables but also the contributing authors who did not manage to make into these listings, as well as all the guest editors of issues recently published in Seminars in Thrombosis $\mathcal{E}$ Hemostasis. Finally, as always, I look forward to seeing future listings!

\section{References}

1 Favaloro EJ. Editorial. Welcome to a special issue of Seminars in Thrombosis \& Hemostasis-the closing issue for 2008. Semin Thromb Hemost 2008;34:693-696

2 Favaloro EJ. A tribute to Eberhard F. Mammen, M.D. (1930-2008). Semin Thromb Hemost 2008;34(8):703-707

3 Favaloro EJ. Editorial. Welcome to the first issue of Seminars in Thrombosis and Hemostasis for 2009. Semin Thromb Hemost 2009;35:1-2

4 Favaloro EJ. Editorial. Winners of the inaugural Eberhard F. Mammen award for Most Popular article. Semin Thromb Hemost 2009; 35:587-590

5 Favaloro EJ. Editorial. 2009 Eberhard F. Mammen Young Investigator award winners. Semin Thromb Hemost 2010;36:469-470

6 Favaloro EJ. Winners of the 2010 Eberhard F. Mammen award for most popular article during 2008-2009. Semin Thromb Hemost 2010;36(7):685-692

7 Favaloro EJ. 2011 Eberhard F. Mammen award announcements. Semin Thromb Hemost 2011;37(5):431-439

8 Favaloro EJ. 2012 Eberhard F. Mammen award announcements. Semin Thromb Hemost 2012;38:425-432

9 Favaloro EJ. Eberhard F. Mammen award announcements. Semin Thromb Hemost 2013;39:567-574

10 Favaloro EJ. 2014 Eberhard F. Mammen award announcements: Part I - Most popular articles. Semin Thromb Hemost 2014;40(4): 407-412

11 Favaloro EJ. 2014 Eberhard F. Mammen award announcements: Part II-Young Investigator Awards. Semin Thromb Hemost 2014; 40(7):718-723

12 Favaloro EJ. 2015 Eberhard F. Mammen award Announcements: Part I-Most Popular Articles. Semin Thromb Hemost 2015;41(7): 673-679
13 Favaloro EJ. 2015 Eberhard F. Mammen award announcements: part II-Young Investigator Awards. Semin Thromb Hemost 2015; 41(8):809-815

14 Favaloro EJ. 2016 Eberhard F. Mammen award announcements: Part I - Most Popular Articles. Semin Thromb Hemost 2016;42(4): 325-330

15 Moore GW. Recent guidelines and recommendations for laboratory detection of lupus anticoagulants. Semin Thromb Hemost 2014;40(2):163-171

16 Favaloro EJ, Lippi G. Laboratory testing in the era of direct or nonvitamin $\mathrm{K}$ antagonist oral anticoagulants: a practical guide to measuring their activity and avoiding diagnostic errors. Semin Thromb Hemost 2015;41(2):208-227

17 Warkentin TE. Heparin-induced thrombocytopenia in critically ill patients. Semin Thromb Hemost 2015;41(1):49-60

18 Cuker A. Clinical and laboratory diagnosis of heparin-induced thrombocytopenia: an integrated approach. Semin Thromb Hemost 2014;40(1):106-114

19 Demers M, Wagner DD. NETosis: a new factor in tumor progression and cancer-associated thrombosis. Semin Thromb Hemost 2014;40(3):277-283

20 Raskob GE, Angchaisuksiri P, Blanco AN, et al; ISTH Steering Committee for World Thrombosis Day. Thrombosis: a major contributor to global disease burden. Semin Thromb Hemost 2014;40(7):724-735

21 Cuker A, Prak ET, Cines DB. Can immune thrombocytopenia be cured with medical therapy? Semin Thromb Hemost 2015;41(4): 395-404

22 Althaus K, Greinacher A. MYH9-related platelet disorders. Semin Thromb Hemost 2009;35(2):189-203

23 Favaloro EJ. Clinical utility of the PFA-100. Semin Thromb Hemost 2008;34(8):709-733

24 Zolfaghari S, Harenberg J, Froelich L, Wehling M, Weiss C. Development of a tool to identify patients' preference for vitamin $\mathrm{K}$ antagonist or direct oral anticoagulant therapy. Semin Thromb Hemost 2014;40(1):121-128

25 Harenberg J, Du S, Krämer S, Weiss C, Krämer R, Wehling M. Patients' serum and urine as easily accessible samples for the measurement of non-vitamin $\mathrm{K}$ antagonist oral anticoagulants. Semin Thromb Hemost 2015;41(2):228-236

26 Nurden AT. Platelet membrane glycoproteins: a historical review. Semin Thromb Hemost 2014;40(5):577-584

27 Wada H, Usui M, Sakuragawa N. Hemostatic abnormalities and liver diseases. Semin Thromb Hemost 2008;34(8): 772-778

28 Italiano JE Jr. Unraveling mechanisms that control platelet production. Semin Thromb Hemost 2013;39(1):15-24

29 Boonyawat K, Crowther MA. Venous thromboembolism prophylaxis in critically ill patients. Semin Thromb Hemost 2015;41(1): 68-74

30 Levi M, Poll Tv. Coagulation in patients with severe sepsis. Semin Thromb Hemost 2015;41(1):9-15

31 Senoo K, Lip GY. Comparative efficacy and safety of the nonvitamin $\mathrm{K}$ antagonist oral anticoagulants for patients with nonvalvular atrial fibrillation. Semin Thromb Hemost 2015;41(2): 146-153

32 Mallett SV. Clinical utility of viscoelastic tests of coagulation (TEG/ROTEM) in patients with liver disease and during liver transplantation. Semin Thromb Hemost 2015;41(5): 527-537

33 McMahon BJ, Kwaan HC. The new or non-vitamin K antagonist oral anticoagulants: what have we learned since their debut. Semin Thromb Hemost 2015;41(2):188-194

34 Ranucci M. Hemostatic and thrombotic issues in cardiac surgery. Semin Thromb Hemost 2015;41(1):84-90

35 Baskurt OK, Meiselman HJ. Blood rheology and hemodynamics. Semin Thromb Hemost 2003;29(5):435-450 
36 Boccardo P, Remuzzi G, Galbusera M. Platelet dysfunction in renal failure. Semin Thromb Hemost 2004;30(5):579-589

37 Riedl M, Fakhouri F, Le Quintrec M, et al. Spectrum of complement-mediated thrombotic microangiopathies: pathogenetic insights identifying novel treatment approaches. Semin Thromb Hemost 2014;40(4):444-464

38 Gando S. Hemostasis and thrombosis in trauma patients. Semin Thromb Hemost 2015;41(1):26-34

39 Intagliata NM, Northup PG. Anticoagulant therapy in patients with cirrhosis. Semin Thromb Hemost 2015;41(5):514-519

40 Semeraro N, Ammollo CT, Semeraro F, Colucci M. Coagulopathy of acute sepsis. Semin Thromb Hemost 2015;41(6):650-658
41 Duga S, Salomon O. Congenital factor XI deficiency: an update. Semin Thromb Hemost 2013;39(6):621-631

42 McEwen BJ. The influence of herbal medicine on platelet function and coagulation: a narrative review. Semin Thromb Hemost 2015; 41(3):300-314

43 Franchini M, Bonfanti C, Mannucci PM. Management of bleeding associated with new oral anticoagulants. Semin Thromb Hemost 2015;41(7):788-801

44 Levi M. Thrombosis and hemostasis issues in critically ill patients. Semin Thromb Hemost 2015;41(1):7-8

45 Favaloro EJ. Anticoagulant therapy: present and future. Semin Thromb Hemost 2015;41(2):109-112 